\title{
GROSS MARGIN AS A CATEGORY FOR EVALUATING THE EFFICIENCY OF PUBLIC SERVICE PROVISION
}

\author{
MARŻA BRUTTO JAKO KATEGORIA OCENY \\ SPRAWNOŚCI ŚWIADCZENIA USŁUG PUBLICZNYCH
}

https://doi.org/10.34739/zn.2021.56.02

\begin{abstract}
Artur J. Kożuch
Poland, Siedlce University of Natural Sciences and Humanities, Faculty of Social Sciences artur.kozuch@uph.edu.pl, ORCID: 0000-0003-0999-3208
\end{abstract}

\begin{abstract}
Contemporary management concepts in public organisations emphasize the adaptation and implementation of selected management methods tested in commercial sector organisations. They are used to improve the processes of providing public services and to ensure savings, especially in terms of the level of costs. One such instrument is variable cost accounting, which, through the gross margin value, allows to assess both the ability of an organisation to provide specific services and to ensure the widest possible range of services, as well as to identify those who are responsible for the functioning of selected responsibility centres. The study attempts to present an algorithm of conduct ensuring the effective use of variable cost accounting in the process of improving the operation of public organisations.
\end{abstract}

Keywords: variable cost accounting, gross margin, efficiency, public services

Streszczenie: Współczesne koncepcje zarządzania organizacjami publicznymi kładą nacisk na adaptację i wdrożenie wybranych metod zarządzania, sprawdzonych w organizacjach sektora komercyjnego. Ich wykorzystanie ma na celu usprawnienie procesów świadczenia usług publicznych i zapewnienie oszczędności, zwłaszcza w zakresie poziomu kosztów. Jednym z takich narzędzi jest rachunek kosztów zmiennych, który poprzez wysokość marży brutto pozwala ocenić zarówno zdolność organizacji do świadczenia określonych usług i zapewnienia ich jak najszerszej różnorodności, jak również zidentyfikować osoby odpowiedzialne za funkcjonowanie wybranych centrów odpowiedzialności. Wskazane w opracowaniu rozwiązania pozwoliły na przedstawienie algorytmu postępowania zapewniającego efektywne wykorzystanie rachunku kosztów zmiennych w procesie doskonalenia funkcjonowania organizacji publicznych.

Słowa kluczowe: rachunek kosztów zmiennych, marża brutto, efektywność, usługi publiczne

\section{Introduction}

Contemporary concepts of the functioning of public organisations put a particular emphasis on their efficiency, drawing the attention of researchers and practitioners to the instruments already tested in the activities of enterprises. Although they often require numerous adaptation processes, in the current state of knowledge their application seems to be one of the most important ways of guaranteeing the quality of public sector activities, both by emphasizing economic effectiveness and by simply setting and controlling the costs of public service provision processes. This is because knowledge in this area is one of the key factors necessitating not so much a limiting of the scope of a sector's operation, but prompting the need to find ways to satisfy the needs of citizens and other stakeholders.

The aim of the research here is to justify the thesis indicating the gross margin as one of the most important instruments for managing the current operations of local government units; and, in this context, suggesting an algorithm of the procedure ensuring the efficiency of the public sector provision processes resulting from the concept of variable cost accounting and at the same time allowing for the accountability of both contractors and the process owners.

The realization of the aim of the work requires answers to a wide range of research questions: 
1. What systems of average production cost accounting can be applied in the management of public organisations?

2. What is the specificity of variable cost accounting and what scope of information does it generate in computational processes?

3. How to determine the scope of the deviation required by the current level of financial resources that can be obtained for the provision of particular public services?

4. What is the optimisation within the scope of fixed and variable costs in the process of the current management of a public organisation?

The research was based on the contemporary literature on the subject concerning the concept of full cost and variable cost accounting as well as elements of financial analysis.

\section{Variable cost accounting as a method of determining an average cost of production}

Contemporary economic practice most often uses two cost accounting models aimed at determining the average cost of production: full and variable cost accounting (Sojak, 2003; Świderska, 2003; Nowak, 2011; Dobija, Kucharczyk, 2014; Czubakowska, Gabrusiewicz, Nowak, 2014).

Full cost accounting in the process of calculating the unit cost of a product uses the historical cost (ex post), assuming that all production costs incurred in a certain period of time relate to specific products or services and as a result they should be fully settled (Nowak, Piechota, Wierzbiński, 2004). Additionally, it is considered here that all cost components are proportional to the production volume. This is the result of treating products and services as basic cost drivers (Kożuch, 2012, 176).

The indicated assumptions cause that the full cost accounting is used to evaluate products at full production cost, including all production costs accounted for as manufactured goods or services and possible production in progress. Nonproduction costs are charged directly to the financial result, without encumbering the finished goods inventory.

Full cost accounting is fully compatible with the principles of external reporting resulting from the Accounting Act (Journal of Laws of September 29, 1994, No. 121, item 591). Therefore, it is mainly used to calculate unit costs for the purpose of inventory valuation and determining the financial result.

The specificity of full cost accounting means that it can be used in the planning processes of the future activity of the organisation as far as longterm decision-making processes are concerned; as well as for those activities that are started and completed within one budget (then, the costs incurred correspond to the expenses made). From the perspective of management sciences, however, it has a number of disadvantages, including in particular the ones connected with the seasonality of the assessment of the tasks or projects covering several budget periods (with a non-closed budget cycle), the increasing scale of the error (distorting the level of unit costs) as a result of using indirect cost accounting on the basis of division keys. Most importantly, without differentiating responsibility centres, it means the impossibility of a proper and reliable disaggregation of the result of the functioning of particular internal structural units, which limits motivational processes aimed at lowering costs and the improvement of the rationality of the activities of responsibility centres (more: Kożuch, 2012, 177-180).

The core of full cost accounting and the method of determining the value of the product costs indicate that there is a need to search for such systems of cost accounting that will be used to search for various costs for different purposes and decision models. One such solution is variable cost accounting, which can be used for the ongoing management of an organisation in a short period of time. It is based on cost classification on the basis of their relation to production volumes distinguishing fixed and variable costs. Costs directly related to the production are considered variable costs, whereas departmental (indirect) costs are divided into variable and fixed costs (Sojak, 2003, 183), and appropriately assigned to costs making up the value or the ones obtained in the income statement.

Variable costs of producing goods incurred in the reporting period are accounted for in complete and incomplete production. Variable production costs of the finished products are then transferred to the financial result, and in the case of finished production sold, or to the balance sheet if the production is in progress or unsold finished production. At the same time, however, what is important for any consideration concerning public organisations, in the case of completed services, it is not possible to create their inventories, therefore they will not appear on the balance sheet (more: Kożuch, 2012, 181).

Fixed indirect manufacturing costs are accounted for directly in the financial result. The so-called non-production costs (of the general management and sales) are treated similarly. However, this is a kind of simplification as there can be also variable costs included in the category.

From the perspective of management science, the main advantage of variable cost accounting is 
the elimination of fixed costs "hidden" in unsold products (this phenomenon is often referred to as cost activation), which - as a result of reducing the influence through the level of inventories on the financial result, reflects the impact of changes in the use of the degree of production capacity on the level of generated operating costs. This enables managers to make decisions concerning the ongoing optimisation of the scope and structure of the production and differentiate the prices of individual products and services. It also enriches the cost control tools (Gabrusewicz, KamelaSowińska, Poetschke, 2000).

Variable cost accounting also makes it possible to learn the scale of the burden that fixed costs constitute in the unit's activity and provides the basis for seeking solutions that will limit their size, thus reducing the effects of the so-called production readiness.

The assessment of the possibility of applying variable cost accounting indicates, however, that it can be used to improve the use of the production capacity of individual generation links by assessing particular stages of activities, both complying with the budget cycle of a given unit and covering a period longer than a financial year or tasks undertaken in periods shorter than this cycle.

\section{Gross margin as an instrument of management in public organisations}

The most important category calculated in the course of the procedure required by the variable cost accounting is the gross margin (although perhaps due to the specificity of the public sector, the term coverage amount should be used). In the standardized approach, it is the difference between total realised revenues and total variable costs, or on a unit basis it is the difference between the selling price and the unit variable cost. In the theory concerning public organisations, it is postulated that the revenues of "for the sale of" were recognised as the value of funds that a given unit is able to allocate to the implementation of a given public service (Fig. 1). This value is the equivalent of socially acceptable funds allocated in the budget for the implementation of particular public services or the purchase price of public services in other public or private sector entities, while maintaining the possibility of control over the continuity of these services - in total, they will constitute the sum of budgetary income and revenues (more in: Kożuch, 2012, 181).

The indicated relations mean that the task of the gross margin in public organisations - in addition to supporting the calculations of unit variable costs - is to determine the initial level of budget funds necessary for the implementation of tasks related to the achievement of current goals. This is because the assessment of the level of predetermined and non-predetermined costs, both in the area of variable and fixed costs, allows for the establishing of the amount of required replenishment, and at the same time it becomes the basis for looking for possible savings related to the course of the process and the conditions for its implementation.

The use of gross margin in the decision-making processes of public organisations is also possible and advisable due to the fact that in these organisations, in most cases, the number of services provided is equal to the number of public services provided to recipients, i.e. the production size is equal to the sales volume. In this case, the calculated financial result is the same, regardless of the chosen method of calculating costs, but in planning processes in public organisations it should be zero, while the use of the gross margin for improvement processes should result in some savings (see Fig. 1), which they will provide with an added value from the actions taken.

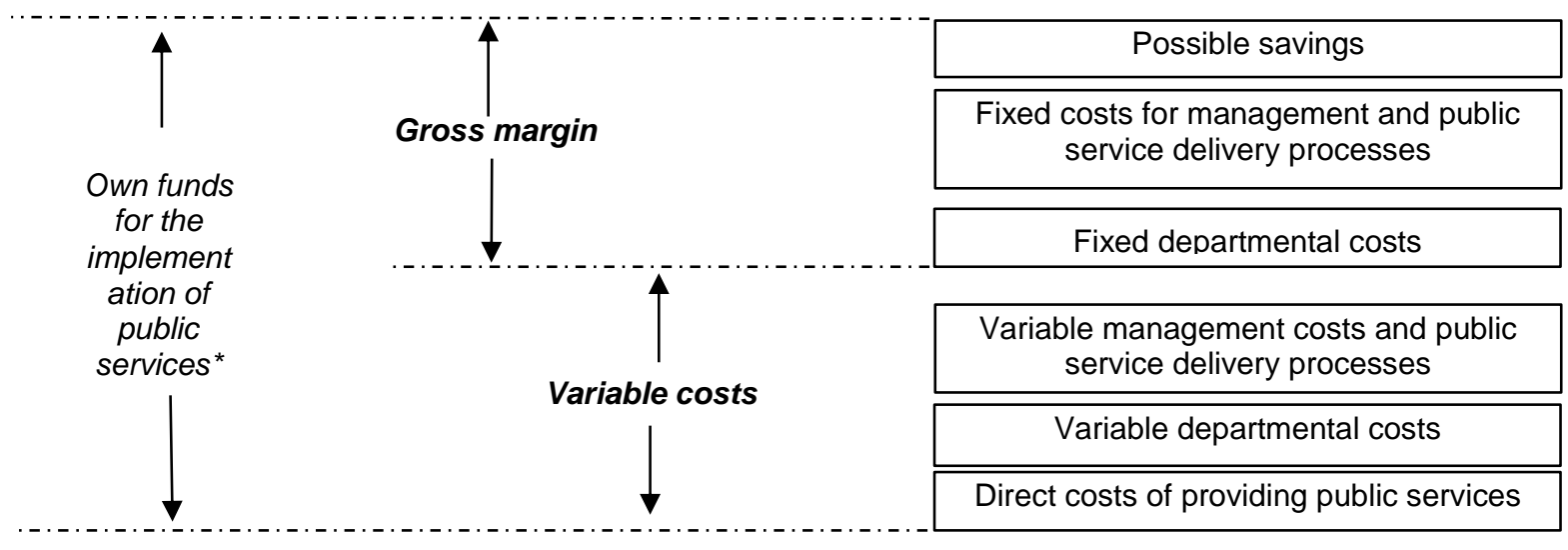

Figure 1. Account of variable costs in public organizations

Source: adapted from Kożuch, (2012), 183. 
An important supplement to the information resulting from variable cost accounting is the possibility of extending its scope by introducing a multi-stage and multi-block perspective. It is a procedure used in relation to the activities of those organisations that want to obtain information concerning the production of multiple products, which requires the allocation of fixed costs to particular lines of goods or individual products. Therefore, each group of costs is subject to identification and allocation to individual cost objects, which in the case of public organisations include: 1. individual services; 2. groups of services, 3. separated elements of the organisational structure or organisational units; 4 . a unit as a whole, etc.

In this approach, fixed costs no longer constitute one block, but consist of many segments, each of which requires at the same time appropriate recording and documentation. This information is the basis for their identification and assignment to distinguished and significant, from the point of view of management, cost objects.

The use of a multi-block and multi-stage variable cost accounting system requires the determination of as many gross margins as necessary for the effective management of the entity. Their number must make it possible to assess the impact of individual facilities on the provision of public services in a given public organisation (Fig. 2).

In the presented model, Gross margin I is direct cost information about the process of producing particular public services. It is an expression of a specific profitability expressed by the difference between what the local community is ready to pay for a given service and - expressing the "manufacturing" process - its variable costs.

The socially acceptable value and the variable cost-generating resources required for the provision of services determine the subsequent "environment" of the public service, expressed in terms of fixed costs, both of production and public organisation.

Gross margin II characterises the activity of a unit by individual cost of production, which includes variable and individual fixed costs, i.e. costs incurred only for the implementation of a given service (Kożuch, 2012, 187). A characteristic feature of these costs is the fact that they disappear when a specific activity is discontinued, e.g. depreciation of premises intended for a specific activity at a given moment, a lease of premises, etc.
The size and structure of the individual cost of production should be subject to constant control of managers of particular centres of responsibility (Kaplan, 1982; Drury, 1991).

At the same time, the specificity of this cost requires that Gross Margins II should be considered the most realistic information about the services provided, where individual fixed and variable costs are not yet distorted by the division keys necessary for further settlements (Horngren, Sundem, 1987).

The value of Gross Margin III informs not so much about one product, but about the production process of particular product groups (in this case services). Fixed costs of these groups are often referred to as standby costs and include, in particular, the value of the consumption of electricity, capital, etc., so the costs that are not subject to or are subject, in a small extent, to control by managers responsible for separate centres of responsibility related to the implementation of particular services. From their point of view, these costs are predetermined and irrelevant to the tasks set for the implementation (Kożuch, 2012, 187), although they should aim at providing adequate funds to cover these costs through the optimisation of Gross Margin II.

In public organisations, reducing the Gross Margin by fixed costs at the stage of assessing the activity gives a value of 0 , which proves that all own funds that can be allocated to the implementation of public services have been used. At the stage of planning and optimisation the value should indicate possible savings.

A basic scope of the applied gross margins (consistent with the model presented in Figure 2) can be extended in order to increase the accuracy of the information generated. In the subject literature, Gross Margin IV can be found and it refers to those components of fixed costs that cannot be assigned to individual costs or costs of groups of services, and the $\mathrm{V}$ gross margin (Nowak, Piechota, Wierzbiński, 2004, 65), which is the difference between Gross Margin IV and fixed costs of the process of providing services. 


\section{Service group $1 \quad(\ldots) \quad$ Service group $n$}

Service $_{1} \quad$ Service $_{2} \quad(\ldots) \quad$ Service $_{\mathrm{n}-1} \quad$ Service $_{\mathrm{n}}$

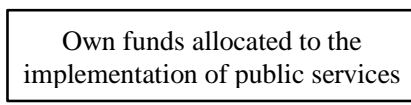

( - ) variable manufacturing costs and service delivery processes

Gross margin I

( - ) individual fixed costs of services

\section{Gross margin II}

\section{Sum of gross margin I i II}

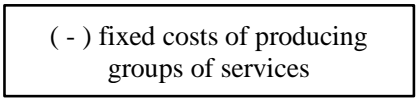

Gross margin III

\section{Sum of gross margin III}

( - ) fixed costs of public organization
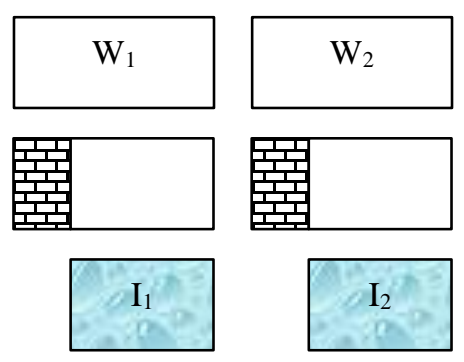

(...)
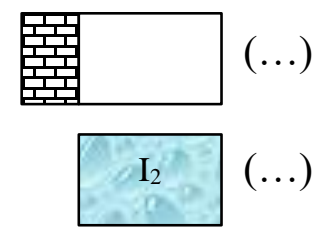

$(\ldots)$
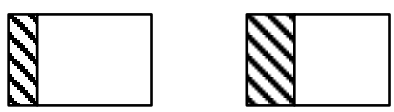

$(\ldots)$
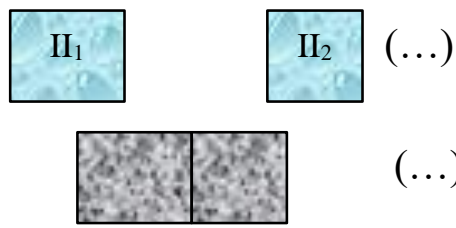

(...)
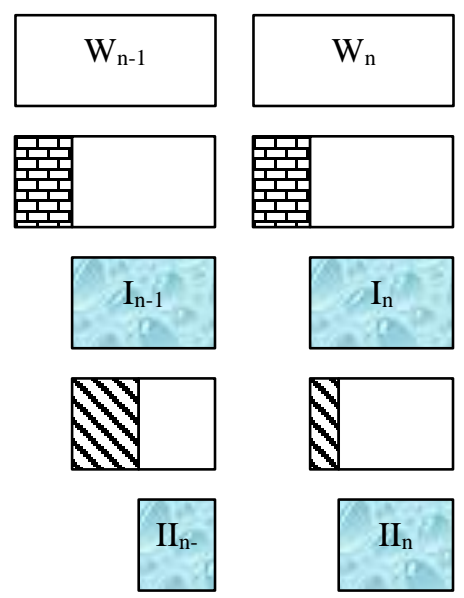

$\mathrm{II}_{\mathrm{n}}$
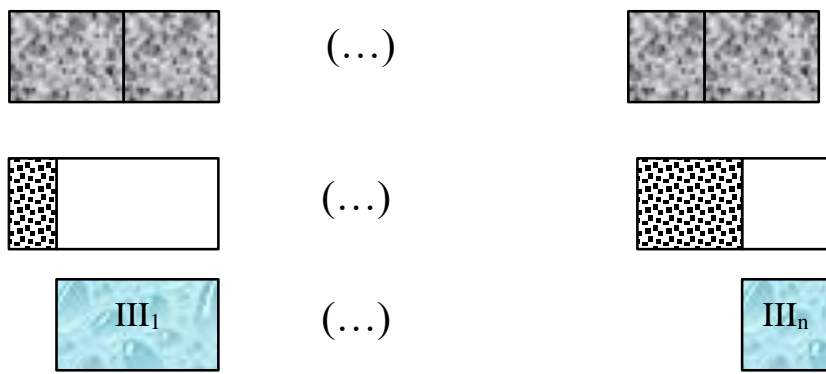

$(\ldots)$

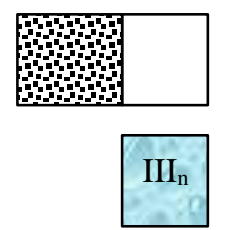

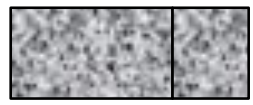

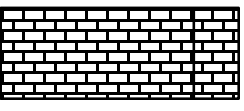

Financial result (or possible savings)

O (lub >0)

Figure 2. Multistage variable cost accounting in public organisations Source: adapted from Kożuch, (2012), 186.

\section{The use of gross margins in optimization processes}

Conducting activities aimed at improving the processes of providing public services requires, in the first place, an audit of the current course of these processes, also in the context of cost intensity. Cost assessment requires the identification of variable and fixed costs. The former result mainly from the "technology of the production process", and therefore from the current course of service provision processes in a given public organisation. The latter, however, are mostly a description of the conditions in which these processes are implemented. The main task in both analytical areas is the assessment of material consumption, labour consumption, capital consumption, energy consumption, service consumption, etc.

The indicated audit process should be supplemented with information on the future value of funds socially acceptable for a given public service, the amount of funds offered by the ordering parties (including the state budget), the value of EU funds that can be obtained by an organisation for a given activity, etc. The difference between the values of funds that could be used in the previous budget period and the funds obtained in the next period determines the size of the total deviation, which provides information about the 
required level of savings necessary to achieve in a given process relating to the provision of services in each of the cost categories.

$$
O w_{K c_{k}}=\sum_{i=1}^{n} \hat{S}_{r p_{y-1}}-\sum_{\mathrm{i}=1}^{n} \hat{S}_{r p} p_{r}
$$

Where:

$n$ - number of possible sources of obtaining funds for the activities of a given public organisation

$O w_{K C k}$ - total required cost deviation of k-service

$S r_{r-1}$ - funds possible to spend in the previous financial year

Srp $p_{r}$ - funds possible to use in the current budgetary period.

It should be remembered that in the suggested solution the deviation applies to all costs; also the ones that are not related to the expenditure in a given financial year. This assumption results from the reimbursement of costs - the cost feature, which requires that, by undertaking any economic intentions, at least payment for the used factors of production should be obtained. The specificity of public organisations, where decisions often cannot be made on the basis of economic calculations, means that the inability to cover the costs is that part of the costs of the period that were paid in the previous budgeting period, or it will be charged to future periods (as a rule, sooner or later the payment for the used production factors must be made).

In accordance with the cost accounting model proposed in Figure 2, the value of the determined deviation should correspond to the sum of the deviations that can be achieved in all cost items identified for the purposes of calculating particular gross margin categories.

$O r_{K c_{k}}=\sum_{i=1}^{R} O r_{K g_{l p}}+\sum_{i=1}^{i} O r_{K z p}+\sum_{i=1}^{m} O r_{K g_{i}}+\sum_{i=1}^{s} O r_{K g_{g}}+\sum_{i=1}^{\mathrm{t}} O r_{K g_{o}}$

Where:

$O r_{K C k}$ - total real (achievable in a given organisation) cost deviation of the k-service

$O r_{K Z w}$ - real deviation of variable costs of production

$O r_{K Z p}$ - real deviation of variable costs of the process

$O r_{K S i}$ - real deviation of individual fixed costs of particular services

$O r_{K S g}$ - real deviation of individual fixed costs of cost groups

$O r_{K S o}$ - real deviation of individual fixed costs of the organisation.
It should also be noted here that there is no possibility and no need to search for standardised relations between the components of the total deviation. The achievement of the intended value may be the result of both proportional reductions in each of the cost categories and a reduction in one of the costs incurred in the provision of a given public service. The proportional lowering of each cost item, however, is the most incorrect action here, and the decisions about the place and method of the cost reduction must ensure at least the current level of selected service features, including among others: quality, availability, legality, etc.

The difference between the total required cost deviation of the k-service and its value that can be achieved in the given operating conditions of the public organisation $\left(O w_{K C k}-O r_{K C k}\right)$ provides information about the amount of funds that must be relocated from other areas of an activity in order to meet the needs of citizens and other stakeholders; which in turn limits the range of optional services provided by a given organisation. At the same time, it is a quantified knowledge of the need for further ameliorative actions, including mainly those related to the "technology of the production process" and the conditions in which public services are provided. In this area, the analysis of the degree of cost judgment is of particular importance, which leads to the search for methods of operation that ensure lower costs, both fixed and variable ones, and, which is more and more often occurring in local government units, the analysis of the adequacy of funds transferred by commissioning authorities or the budget countries.

\section{Conclusions}

The philosophy and procedure of variable cost accounting are appropriate for public organisations, in particular for those planning their budgets in a task-oriented system. The use of gross margins, in particular in the extended version, makes it possible to learn about the impact of individual cost groups on the effectiveness of the process of providing individual public services; and at the same time - especially at the level of gross margin II, it enables the settlement of people responsible for the performance of planned tasks. Therefore, it must be agreed that the choice of variable cost accounting is the result of benefits that can be assigned to it in the activities aimed at improving the management process.

Therefore, the cost optimization process requires the following actions: 
1. Identification of implementation processes involved in providing particular services; and on this basis, distinguishing fixed and variable costs incurred in a given organisation,

2. Determining the degree of prejudging particular types of costs and the possibility of reducing them in the given operating conditions of a public organisation,

3. Determining the amount of the necessary cost reduction and the value of supplementary funds that are not covered by the socially acceptable value or the value of funds that can be obtained for the provision of particular public services,

4. Identification of actions aiming at increasing the scope of the possible reduction of fixed and variable costs in the future periods of the organisation's operation (in this action one should also remember about the emergence of

\section{References}

Czubakowska, K., Gabrusiewicz, W., Nowak, E. (2014). Rachunkowość zarządcza. Metody i zastosowania [Management accounting. Methods and applications]. Warszawa: PWE.

Cooper, R., Kaplan, R.S. (1992). Activity-based systems: Measuring the Costs of Resource Usage, Accounting Horizons (6), 1-13.

Dobija, D., Kucharczyk, M. (2014). Rachunkowość zarządcza. Analiza i interpretacja [Management accounting. Analysis and interpretation]. Warszawa: Wolters Kluwer Polska.

Drury, C. (1991). Management and Cost Accounting. Chapman\&Hall. 2nd edition.

Gabrusewicz, W., Kamela-Sowińska, A., Poetschke, H. (2000). Rachunkowość zarządcza [Management accounting]. Warszawa: PWE.

Horngren, Ch.T., Sundem, G.L. (1987). Introduction to Management Accounting. Prentice-Hall International, 7-th edition.

Kaplan, R.S. (1982). Advanced Management Accounting. Hoboken, New Hersey: PrenticeHall International.

Kożuch, A.J. (2012). Budżetowanie jako instrument zarządzania jednostkami samorządu terytorialnego [Budgeting as an instrument for managing local government units]. Warszawa: Wyd. Naukowe PWN. new needs of citizens and other stakeholders and the disappearance of the needs satisfied by the existing activities).

5. Implementation of new solutions reducing the costs of the manufacturing process and the costs of a readiness to provide public services.

An additional aspect of activities in the field of variable cost accounting in public organisations will be the improvement of management information systems, concerning in particular: the evaluation of the work of responsible persons, generating relevant information for the bodies of the entity, citizens and other stakeholders, task and project management, accounting system development, etc.

Mowen, M.M., Hansen, D.R., Heitger, D.L. (2014). Cornerstones of Managerial Accounting, Cengage Learning.

Nowak, E. (2011). Rachunkowość zarządcza $w$ przedsiębiorstwie [Management accounting in an enterprise]. Warszawa: CeDeWu.

Nowak, E., Piechota, R., Wierzbiński, M. (2004). Rachunek kosztów w zarządzaniu przedsiębiorstwem. [Cost accounting in business management]. Warszawa: PWE.

Nowak, E., Wierzbiński, M. (2010). Rachunek kosztów. Modele i zastosowania [Cost accounting. Models and applications]. Warszawa: PWE.

Sojak, S. (2003). Rachunkowość zarządcza [Management accounting]. Toruń: Wyd. Dom Organizatora.

Szychta, A. (2008). Etapy ewolucji i kierunki integracji metod rachunkowości zarządczej [Stages of evolution and directions of integration of management accounting methods]. Łódź: Wyd. UŁ.

Świderska, G.K. (2003). Rachunkowość zarządcza i rachunek kosztów [Management accounting and cost accounting]. Warszawa: Difin. 